Vol 2 No 1 (2018) Page $124-130$

JURNAL OBSESI : JURNAL PENDIDIKAN ANAK USIA DINI

Research \& Learning in Early Childhood Education

https://obsesi.or.id/index.php/obsesi

\title{
Increasing Religious Value through Singing Methods \\ to Students of Kindergarten
}

\author{
Riwayati Zein ${ }^{\bowtie 1}$ Sukmayanti $^{2}$ \\ PG-PAUD STKIP Adzkia Padang - Sumatera Barat
}

\begin{abstract}
Abstrak
Penelitian ini dilakukan sebagai respon terhadap masalah bahwa pembelajaran siswa TK Adzkia V Padang dalam nilai-nilai agama berdasarkan masih rendah. Sementara itu, nilai-nilai agama adalah salah satu aspek yang perlu dirangsang dalam mengajar siswa TK di kelas B. Masalah yang ditemukan di lapangan adalah: 1) Hanya 5 anak yang dapat sembahyang dan 11 siswa lainnya tidak dapat berdoa dan mengangkat tangan mereka sambil berdoa. 2) Dalam praktek sholat 6 anak dapat melakukan dengan baik sedangkan 10 anak lainnya melakukan sholat yang terburu-buru bahkan berteriak-teriak. Tujuan penelitian ini adalah untuk mendeskripsikan peningkatan nilai-nilai agama melalui metode nyanyi dalam mengajar siswa TK B Adzkia V Padang. Penelitian ini merupakan penelitian tindakan kelas (action research) yang dilaksanakan dalam 2 siklus. Desain setiap siklus dilakukan dalam 5 pelajaran melalui empat tahap: perencanaan, pelaksanaan tindakan, observasi dan refleksi. Teknik pengumpulan data dilakukan dengan observasi dan dokumentasi. Dengan demikian, data dianalisis menggunakan statistik deskriptif. Hasil siklus II menunjukkan peningkatan nilai agama anak cukup signifikan hingga mencapai $90 \%$ dan penelitian dinyatakan berhasil. Dengan demikian, dapat disimpulkan bahwa penelitian metode nyanyi dapat meningkatkan nilai-nilai agama anak-anak di taman kanak-kanak B Adzkia V Padang.
\end{abstract}

\section{Kata Kunci: Nilai-nilai agama dan metode Menyanyi}

\begin{abstract}
This research was conducted as the response to the problem that the learning of kindergarten students of Adzkia V Padang in religious values based is still low. Meanwhile, religious values are one of the aspects that need to be stimulated in teaching kindergarten students in class B. Problems which are found in the field are: 1)Only 5 children who can pray well and other 11 students cannot pray and raise their hands while praying. 2) In the practice of praying 6 children can perform well while the other 10 children perform the praying a hurry even shouting. The purpose of this study is to describe the increase of religious values through the method of singing in teaching kindergarten B students of Adzkia V Padang. This research is a class action research (action Research) which was carried out in 2 cycles. The design of each cycle was conducted in 5 lessons through four stages: planning, action implementation, observation and reflection. The data collection technique was done by observation and documentation. Thus, the data was analyzed using descriptive statistics.The results of cycle II shows the increase of religious values of children is significant enough to reach $90 \%$ and the study is declared successful. Thus, it is concluded that the research of singing method can increase the religious values of children in kindergarten B Adzkia V Padang.
\end{abstract}

Keywords: Religious values and Singing method

@ Jurnal Obsesi Prodi PG-PAUD FIK UPTT 2018

$\triangle$ Corresponding author :

Address : Elang Raya Street $5^{\text {th }}$ Air Tawar Barat, Padang

Email : riwayati.zein@yahoo.com

ISSN 2356-1327 (Media Cetak)

Phone : 081371822011 


\section{BACKGROUND}

Early age is the period of life in the development of human life. This period is a potential time to develop various aspects of child development. According Busthomi (2012: 16) 50\% child development occurs at the age of $0-5$ years. The importance of this period is the initial foundation for child growth. The value of religion is one aspect of development in the early childhood learning process. If at this time the child received less attention, supervision and care is feared the child has not developed optimally.

The value of religion has an important role in shaping the personality of a person because this as a foundation for him in living life. Sturdy personality of a child will be directed in his life someday, because the meaning of religious values will be a guide and useful for human life both born and inner. This is supported by the Muslim hadith narration (1030-1031) which states that: "Every child born in the nature of fitrah, both parents who make it Jewish, Christian and Majusi". This hint suggests to parents need stimulation and guidance since early religious teachings so that children have a good philosophy of life. It is believed that the stimulation and guidance of religion in the learning process to help children make themselves understand the norms of life according to the views of their parents.

The problem of religious values in the kindergarten B children Adzkia V Padang was originally inspired by a reality in the daily behavior of children who have not reflected the personality of noble character, such as politeness in behaving according to religious demands. This indicates that there is something that needs to be improved, according to the pre-school education objectives is the basis for the growth and development of life later that required a stimulation of the development of religious values. Citing the opinion of Armstrong (2009: 183) that value is the development and introduction of history and philosophy that serves to enhance the cultural value and symbol system. It is believed that religious values can be introduced to children such as the history of the childhood life of Prophet Muhammad SAW whose conditions contain the teachings of behavior and values of life. The value of life is rooted in the value of religion for example a devout person worship symbolic life is calm because it is guided by the wisdom of worship he did. The child's mental-spritual recognition and stimulation effort is based on several considerations.
First stage development of religious values of children aged 4-6 years is practice of prayer. Supposedly, the child is able to perform the practice of prayer in an orderly manner. This is supported by the opinion of Sabiq (1994: 274-275) which states that: O people pray in a low voice, ... God is AllHearing, All-Seeing. "The gentle voice of prayer is likened to dealing with the most respected the hope of what it wants to be, one of God's all-hearing attributes and even the movement of the human heart is known to Him, so there is no need to shout when praying, All seeing its meaning because of His greatness we can not hide, including the attitude of prayer. The empirical facts show that the movement praying children and read the prayers in a hurry and even shouting. This condition if left early then the child considers prayer as an activity without meaning and without rules so feared they are less convinced that Allah is Assami 'and AlBashar when the meaning of prayer praying solemnly. Thus it is concluded that in general the children have not done practice well prayer.

Implanting religious values in kindergarten children needs to be adjusted to the nature of children's learning is denagn pleasant atmosphere and approach appropriate to the development of children. During this introduction of religious values in children Adzkia V Padang kindergarten performed by habituation method. But it has not succeeded in motivating the child in praying before and after doing activities and the child has not yet been able to practice praying in an orderly fashion. Several times tried by the method of singing to invite children to pray by using a symbolic movement by holding both hands and praying quietly. It turns out motivated children to pray well and be disciplined to perform the prayer movement with a song that contains a message about the prayer.

Characteristic of religious values according to Permendikbud (2014: 21) that is to say a prayer before and after doing activities and doing worship. The graduation standard (SKL) of children in the development of religious values of children in kindergarten must be in accordance with the level of achievement of its development which is integrated in everyday activities. Religious values according to Hidayat (2004: 7.10) serve to show about good behavior that can be done and bad behavior that is not good done. Further Berk (2009: 498) reveals several things: 1) Religion to form and prepare the younger 
generation to enter adulthood based on the moral values it embraces. 2) The result of youth religious education is possible to teach each other in discussions of moral issues and improvement of life. 3) Good feelings toward others. Enhance and strengthen life among people to interact and have social value. Expert opinion above understood that ideally children from an early age have good behavior and have independence in implementing independent elements.

The approach to religious values according to Hidayat (2005: 11.6) can be done by: 1) Playing a role, playing a role or object around it so that children get to know real religious life in learning. For example, playing a role to introduce the story of Prophet Ibrahim. 2) Field trips, children brought religious tours such as field trips to places of worship to know the greatness of God, know the rules and attitudes when in the place of worship and stimulated to perform worship. 3) Conversational to develop the skills of listening and speaking so that children can construct religious values such as teachers tell about the exemplary nature of the apostle. 4) Demonstration, by demonstrating an object, object, a process related to religious concept such as practice berwudhuk, practice of prayer. 5) Singing, teachers and parents can use to illustrate religious virtues and values.

Classroom learning is situational with the complexity of problems that become the tasks and responsibilities of teachers so that learning is conducive. Early childhood teachers will be more effective in implementing learning with a variety of methods so that children do not get bored. Learning method is a procedure used by teachers systematically and comprehensively to achieve learning objectives. Be sure that learning methods are structured comprehensively, systematically without contradictions so that the active participation of students when learning is an indicator of teacher success. Muslicatoen (2005:17) explains that many classroom learning methods can be used for stimulating and motivating children, one of which is by singing.

Singing method is one way to create an attractively attractive class. A song for children expressing the message, the message that moves the soul because it has the imagination of beauty through words combined with the music. Referring opinion Kamtini and Tanjung (2005: 116) states that the music encourages children to move and can to calm down.
Children's songs have certain characteristics: unique, simple, according to the character of the child's voice. The lyrics of children's songs serve to stimulate the deepening of character, affection, educate and tell the culture, the rules of life and social functions.

Singing is one way to stimulate children's religious values. Benefits of singing to children according to Masitoh (2005: 1.13) 1.) Encourage the learning of children and make the class feel alive, 2) Development of education character, children interactions, singing is fun, 3) Overcoming anxiety, expressing anxiety, 4) Singing can build confidence and help memory. Thus in accordance with the statement Rahmawati (2005: 74) that singing can develop children's creativity.

Based on the background explanation of the above problem, the formulation of this research problem is: "How to increase the value of religion through the method of singing children kindergarten B Adzkia V Padang?". The purpose of this study is to describe the increase in religious values through the method of singing for children kindergarten B Adzkia V Padang.

\section{RESEARCH METHODS}

This study is a classroom action research (PTK) developed by Arikunto (2015:3) using a continuous cycle and each cycle is carried out in 5 actions. PTK according to Arikunto (2015: 194) is an action to improve the quality and learning process that improves learning outcomes. The research procedure consists of planning, execution, observation and reflection. Arikunto (2015: 143) explains that planning in PTK is to design details of what activities and how the implementation of action on each cycle as a guide for researchers.

1) The planning phase starts from the preparation of RPPM and RPPH that is adapted to the theme of learning. The action plan (RPT) of cycles 1 and 2 is arranged in a table that contains: learning materials and objectives, learning activity schedules, methods, media and assessment. 2) Implementation by Arikunto (2015: 145) is a core activity in PTK. Implementation phase of action is applying new way of teaching on classroom study consist of two cycles. 3) Observation stage is the stage of activity to collect some information to monitor and correct the implementation of the action in accordance with the RPT is prepared. 4) The 
reflection stage is a checking step on the implementation action that has been designed. Reflections are supplemented with a note of weaknesses as a basis for improvement for the preparation of re-action plans in the following cycle.

Data collection techniques from this study consisted of: observation by checklist technique as concrete data to see the development of children learning outcomes. Observation according to Whortman (2005: 93 ) is a direct method to evaluate the development of children's learning. Based on the opinion of Whortman it is believed that for direct learning evaluation in this study use observation sheet.

Data analysis technique using simple percentage formula presented by Arikunto (2010: 112):

$P=\frac{F}{N} \times 100 \%$

Information:

$$
\begin{aligned}
& \mathrm{P}=\text { Percentage } \\
& \mathrm{F}=\text { Frequency } \\
& \mathrm{N}=\text { Number of learners }
\end{aligned}
$$

The ability of children is said to increase if the percentage of child achievement increases from previous learning outcomes. Determination of the increase and interpretation of children's learning activities using Arikunto classification (2015: 106) as follows: $76 \%-100 \%=$ Very good developing (BSB), $51 \%-75 \%=$ Expanding as expected $(\mathrm{BSH}), 25 \%-50 \%=$ Start developing $(\mathrm{MB})$, and $0 \%-25 \%=$ Not developed (BB). The hypothesis of this action research that "Singing methods implemented in learning can improve the religious values of the kindergarten children B Adzkia V Padang".

Table 1. Rating Scale of Increasing the Religious Value of Kindergarten Adzkia V Padang

\begin{tabular}{|c|c|l|}
\hline Skor & Rate & \multicolumn{1}{|c|}{ Information } \\
\hline 4 & BSB & $\begin{array}{l}\text { Children are able to pray well } \\
\text { without help } \\
\text { Children are able to do good } \\
\text { worship without being helped }\end{array}$ \\
\hline 3 & BSH & $\begin{array}{l}\text { Children are able to pray well } \\
\text { but are rarely helped } \\
\text { Children are able to do worship } \\
\text { well but rarely assisted }\end{array}$ \\
\hline 2 & MB & $\begin{array}{l}\text { The lazy child is able to pray } \\
\text { well but is often helped }\end{array}$ \\
\hline
\end{tabular}

\begin{tabular}{|c|c|l|}
\hline Skor & Rate & \multicolumn{1}{|c|}{ Information } \\
\hline & & $\begin{array}{l}\text { Lazy children are able to do } \\
\text { worship well but often assisted }\end{array}$ \\
\hline 1 & BB & $\begin{array}{l}\text { Not able to pray and always be } \\
\text { helped } \\
\text { Not able to do worship and } \\
\text { always assisted }\end{array}$ \\
\hline
\end{tabular}

\section{RESEARCH RESULT AND DISCUSSION}

The application of the singing method starts from the initial activity. The teacher starts the lesson by saying hello. After apperception, the teacher mentioned the theme of the day's lesson "love the homeland because of god" sub theme of my city. The child sat in a circle reading the pledge, praying and repeating the short Surah. Teachers show how to pray and after that teachers read the meaning of Surah Al Araf and Surah Al Isra. After that the teacher appoints a child to lead the singing, about the prayer with the movement according to the meaning of the song. All children sing a song while holding a picture of praying "when I pray, I raised my hands, in a soft voice, not shouting, praying earnestly, in order to be granted any request of the faithful man". After the practicing, the children are asked to demonstrate in front of the class about the right procedure of praying. After that the teacher invites other children to applaud and appreciate the children by giving stickers pictures of people praying and how to pray. Furthermore, teachers remove praying activities by inviting children by saying hamdalah.

After that continued with dhuha prayer. This activity begins with a song to know how to perform wudhu. The teacher uses the movement of songs about the prayer; the children follow the song with the movement. Furthermore, the teacher asked about the procedure of praying dhuha completed with the core activities

An overview of religious values improvement through the singing method of action cycle 1 on 5 meetings.

Table 2. Summary of Improved Religious Values through Singing Methods in Kindergarten B Adzkia V Padang Cycle 1 


\begin{tabular}{|c|c|c|c|c|c|c|c|}
\hline \multirow{2}{*}{$\begin{array}{c}\mathrm{N} \\
\mathrm{O} \\
\end{array}$} & \multirow{2}{*}{$\begin{array}{c}\text { Aspec } \\
\text { ts }\end{array}$} & \multicolumn{5}{|c|}{ Meeting } & \multirow{2}{*}{$\sum_{\%}$} \\
\hline & & 1 & 2 & 3 & 4 & 5 & \\
\hline 1. & $\begin{array}{l}\text { Pray } \\
\text { before } \\
\text { and } \\
\text { after } \\
\text { activiti } \\
\text { es }\end{array}$ & $\begin{array}{l}24 \\
\%\end{array}$ & $\begin{array}{l}24 \\
\%\end{array}$ & $\begin{array}{l}24 \\
\%\end{array}$ & $\begin{array}{l}54 \\
\%\end{array}$ & $\begin{array}{l}69 \\
\%\end{array}$ & $\begin{array}{l}39 \\
\%\end{array}$ \\
\hline 2. & $\begin{array}{l}\text { Do } \\
\text { worshi } \\
\text { p }\end{array}$ & $\begin{array}{l}15 \\
\%\end{array}$ & $\begin{array}{l}24 \\
\%\end{array}$ & $\begin{array}{l}24 \\
\%\end{array}$ & $\begin{array}{l}30 \\
\%\end{array}$ & $\begin{array}{l}59 \\
\%\end{array}$ & $\begin{array}{l}36 \\
\%\end{array}$ \\
\hline \multicolumn{7}{|c|}{ Average } & $\begin{array}{l}38 \\
\%\end{array}$ \\
\hline
\end{tabular}

Table 2 above shows the general improvement of results achieved by children in the 1 st cycle is still low obtained an average yield of $38 \%$ and not in accordance with predetermined success indicator achievement. The result of cycle 1 is illustrated in the following graph:

Graph 1. Recapitulation Improved Religious Values through Singing Methods in Kindergarten B Adzkia V Padang Cycle 1

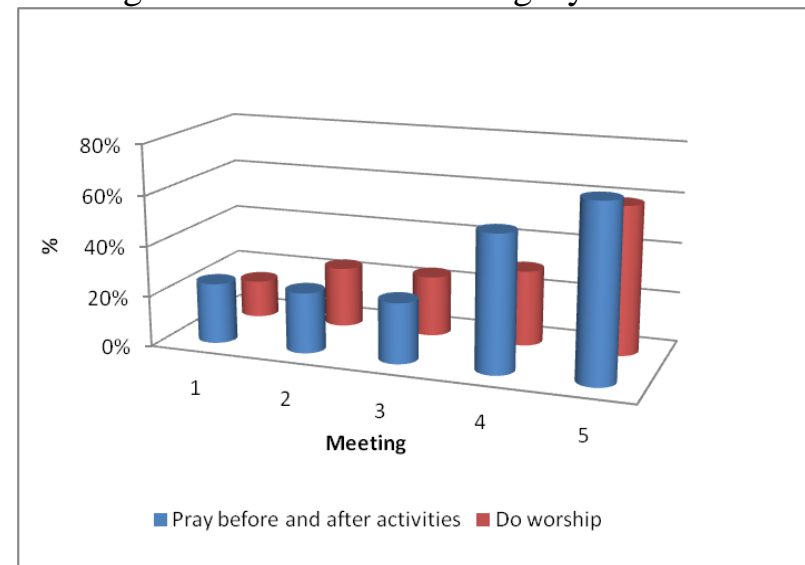

Reflection is a review of the planning, implementation, observation and evaluation of research components by berkaloborasi between researchers with observers. The result of evaluation cycle 1 shows that in general the average achievement of children for both aspects observed low criterion, then continued on cycle 2 . Illustration of the results of cycle 2 can be seen in the table below:

Table 3. Summary of Improved Religious Values through Singing Methods in Kindergarten B Adzkia V Padang Cycle 2

\begin{tabular}{|c|c|c|c|c|c|c|c|}
\hline $\mathrm{o}$ & & 1 & 2 & 3 & 4 & 5 & \\
\hline 1 & Pray before & 85 & 91 & 94 & 96 & 99 & $93 \%$ \\
\hline & $\begin{array}{l}\text { and after } \\
\text { activities }\end{array}$ & $\%$ & $\%$ & $\%$ & $\%$ & $\%$ & \\
\hline 2 & Do W/rohin & 69 & 85 & 92 & 95 & 98 & $88 \%$ \\
\hline & Do worsnip & $\%$ & $\%$ & $\%$ & $\%$ & $\%$ & \\
\hline \multicolumn{7}{|c|}{ Average } & $90 \%$ \\
\hline
\end{tabular}

Table 3 above shows that in general the improvement of outcomes achieved by children in cycle 2 has increased. The average yield obtained $90 \%$ with this is in conformity with the predicted success indicators of achievement. The result of cycle 2 is illustrated in the following graph:

Graph 2. Recapitulation Improved Religious Values through Singing Methods in Kindergarten B Adzkia V Padang Cycle 2

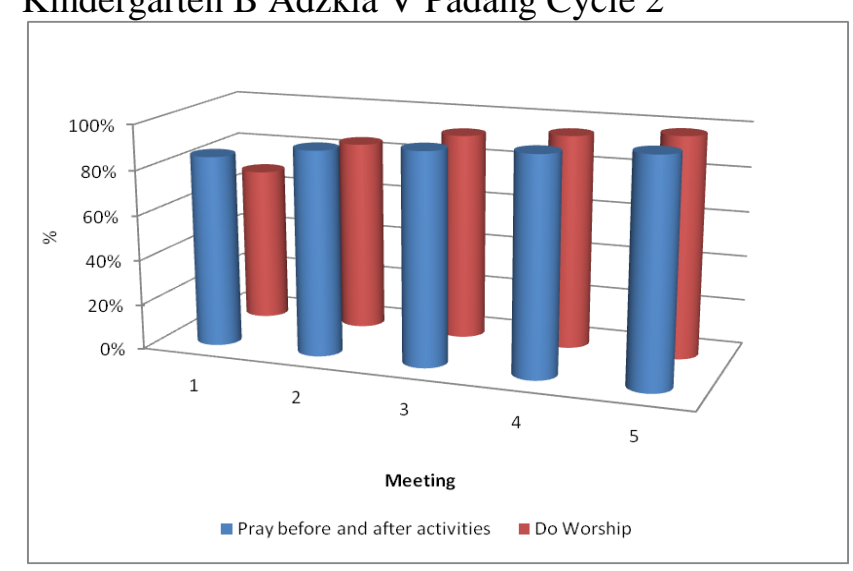

Table 4. Summary of Improved Religious Values through Singing Methods

\begin{tabular}{|c|l|c|c|c|}
\hline NO & Aspects & $\begin{array}{c}\text { Pre- } \\
\text { cycle }\end{array}$ & $\begin{array}{c}\text { Cycle } \\
\mathbf{1}\end{array}$ & $\begin{array}{c}\text { Cycle } \\
\mathbf{2}\end{array}$ \\
\hline $\mathbf{1}$ & $\begin{array}{l}\text { Pray } \\
\text { before and } \\
\text { after } \\
\text { activities }\end{array}$ & $23 \%$ & $39 \%$ & $93 \%$ \\
\hline $\mathbf{2}$ & $\begin{array}{l}\text { Do } \\
\text { worship }\end{array}$ & $15 \%$ & $36 \%$ & $88 \%$ \\
\hline & Equal & $\mathbf{1 9 \%}$ & $\mathbf{3 8 \%}$ & $\mathbf{9 0 \%}$ \\
\hline
\end{tabular}

Table 4 shows that in general there is an increase in child learning development ranging from the average pre- action yield of $19 \%$, the average result of the cycle $138 \%$, and the average yield cycle $290 \%$. Based on this it is stated that this research succeed to improve the religious value of kindergarten $\mathrm{B}$ children Adzkia V Padang through singing method.

Graph 3. Recapitulation Improved Religious Values through Singing Methods in Kindergarten B Adzkia V Padang Cycle 2 


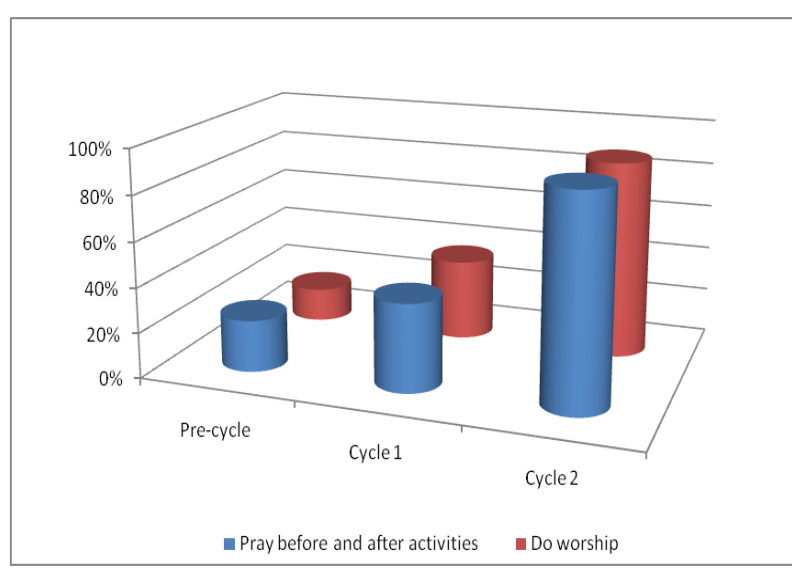

\section{DISCUSSION}

The purpose of this study is to describe "Improvement of the religious values of Adzkia V Padang kindergarten through the method of singing". Based on the findings of the research then discussed some of the following:

\section{Pray before and after the activity}

The results of the first cycle study showed that the development of children in prayer before learning in general is still low. Children are still not focused when praying so that most children pray while doing something. The child is reciting a prayer while shouting so that the other children who are solemn in prayer become disturbed. The activity of praying after conducting activities in general is still low. The child is still not used to praying after studying or praying after meals and always praying after hearing the instructions from his teacher. This is supported by Berk (2009: 496) many research results indicate that religious values contribute and are united to the pen, order and resolve the moral issues in the arrangement of life patterns. Based on this condition, the level of achievement that has been determined $75 \%$ has not been achieved therefore it is continued in cycle 2 .

The results of the research cycle 2 shows that in general the development of children in praying after the activity has begun to increase. The child no longer prays as he does something and the child recites the order with his hands and reads the prayer in a low voice. Children are accustomed to praying after learning and after eating in order without shouting. Based on this condition, the level of achievement that has been determined $75 \%$ has been achieved. It is hereby stated that the singing method can increase the religious values of the children in prayer before and after the activity. Thus it is stated that this research was successful to increase the religious values of Adzkia $\mathrm{V}$ Padang kindergarten children. This is in accordance with the opinion of Mashitoh (2005: 113) that, "Singing is an expression of one's feelings of pleasure through tone and poem.For the development of religious values used Islamic songs, children are accustomed to easily do it.

\section{An increasing picture of worship}

The results of research cycle 1 shows that the development of children in doing worship in general is still low. Children still not focus when praying practice, most children do it while joking with friends. Prayer movement is not correct and the child is just standing up and sitting or walking and disturb friends so that other friends disturbed. The child is still not used to the practice of prayer and always hear the command of his teacher is just the right order.

This is supported by Hidayat's opinion (2004: 87) that, "Characteristics of the development of religious values of children is the formation of behavior in every activity carried out in daily activities on a regular basis. Through this program the child is expected to perform activities of worship well. The formation of behavior based on religious values Based on this condition and supported by the result of achievement rate that has been determined $75 \%$ has not been achieved therefore it is continued in cycle 2 .

The results of the research cycle 2 shows the general development of children practice worship has significantly increased. The child has consciously started preparing himself for dhuha prayer for example asking permission to the teacher wudhuk. Children are accustomed to pray dhuha with orderly without having in command by the teacher and not shout. Prayer activities together have begun orderly. One of the children acts as a priest. This condition is supported by the achievement of $75 \%$ achievement that has been determined. The research of singing method has been able to increase the religious values of children in prayer before and after activity. In accordance with Kamtini and Tanjung (2005: 118), the strength of children's songs for learning helps develop intelligence, social values and psychomotor. Thus stated research methods of singing succeeded to increase the religious values of children in kindergarten Adzkia $\mathrm{V}$ Padang.

\section{GREETING SPEECH}


The success of this research cannot be separated by the help of various parties. On this occasion the researcher would like to thank the Head of Kindergarten Adzkia V Padang who has facilitated the implementation of this research. Not to forget the same greeting is also intended for colleagues so that harmonization occurs during the process of this research. May Allah repay all goodness, Aamiin.

\section{REFERENCES}

Ananda, R. (2017). Implementasi Nilai-Nilai Moral dan Agama Pada Anak Usia Dini. Jurnal Obsesi : Journal Of Early Childhood Education, 1(1), 19-31. doi:10.31004/obsesi.v1i1.22

Arikunto, Suharsimi. 2015. Penelitian Tindakan Kelas. Jakarta: Bumi Aksara.

Armstrong, Thomas. 2009. Multiple Intelligences in The class Room. Alexandria : ASCD Publication Press.

Berk, Laura E. 2006. Child Development. London: Prentice Hall, Inc.

Busthomi, Yazid. 2012. Panduan Lengkap PAUD Melejitkan Potensi dan Kecerdasan Anak Usia Dini. Bandung : Citra Publishing.

Hadis Riwayat Muslim. 2009.Syarah Riyadhus Shalihin, Jilid 2 Cetakan 2. Jakarta : Darussalam Press.

Hidayat,Otib Hidayat.2004. Metode PengembanganMoral dan Nilai-Nilai Agama. Jakarta : Pusat Penerbitan Universitas Terbuka.

Kamtini dan Husni Wardi Tanjung. 2005. Bermain Melalui Gerak dan Lagu. Jakarta : DIKTI Direktorat Pembinaan Tenaga Pendidik dan Ketenagaan Perguruan Tinggi.

Fauziddin, M. (2016). Pembelajaran Agama Islam melalui Bermain pada Anak Usia Dini (Studi Kasus Di TKIT Nurul Islam Pare Kebupaten Kediri Jawa Timur). Jurnal Obsesi : Journal Of Early Childhood Education, 2(2), 8-17. doi:10.31004/obsesi.v2i2.52

Moeslichatoen. 2005. Metode Pengajaran di Taman Kanak-Kanak. Jakarta: Rineka Cipta.

Masitoh. 2005. Strategi Pembelajaran di TK. Jakarta; Universitas Terbuka

Peraturan Menteri Pendidikan Nasional RI Nomor 137 tahun 2014 tentang Standar Pendidikan Anak Usia Dini, Nonformal dan Formal. Jakarta : Kemendikbud.
Purwanto. 2010. Evaluasi Hasil Belajar. Yokjakarta : Pustaka Pelajar.

Rachmawati, Yeni. 2005. Strategi Pengembangan Kreativitad pada Anak Usia Taman Kanak-Kanak. Jakarta : DIKTI Direktorat Pembinaan Tenaga Pendidik dan Ketenagaan Perguruan Tinggi.

Sayyid,Sabiq, M. 1994.Terjemah Fiqih Sunnah. Jilid 4 cetakan I. Bandung: PT Al Ma'rif.

Whorthman, Sue C. 2005. Assessment in Early Childhood Education Fourth Edition. New Jersey:Pearson Education. 